\title{
Persepsi Wali Murid SMPN 18 Padang terhadap Pelaksanaan Kebijakan Sistem Zonasi dalam PPDB
}

\author{
Sri Fifin Silpana \\ Prodi Pendidikan Pancasila dan Kewarganegaraan \\ FIS Universitas Negeri Padang \\ E-mail: fifienirwandi@gmail.com
}

\begin{abstract}
ABSTRAK
Penelitian ini bertujuan untuk mendeskripsikan pengetahuan pelaksanaan dari kebijakan sistem zonasi, serta teknis pelaksanaan kebijakan sistem zonasi pada penerimaan peserta didik baru di SMP N 18 Padang. Jenis penelitian ini adalah deskriptif dengan pendekatan kuantitatif. Populasi dari penelitian ini adalah 870 serta sampel dari penelitian adalah 90 responden. Dengan teknik pengambilan sampel munggunakan teknik probability sampling. Dimana pada penelitian ini, responden yang dimaksud adalah wali murid dari kelas VII, VII dan IX di SMP N 18 Padang. Kebijakan ini dilakukan pada saat pelaksanaan penerimaan peserta didik baru dimana pelaksanaanya yaitu calon peserta didik harus bersekolah dengan jarak terdekat dari domisili atau sesuai dengan Kartu Keluarga. Sehingga pada penelitian ini mendapat temuan bahwa masyarakat yang dalam hal ini peneliti meneliti wali murid di SMP N 18 Padang ditinjau dari dua aspek yaitu aspek persepsi masyarakat terhadap pemahaman pelaksanaan kebijakan sistem zonasi pada PPDB dan aspek persepsi masyarakat terhadap sosialisasi pelaksanaan kebijakan sistem zonasi. Adapun hasil dari penelitian ini mencapai $61 \%$ dengan kategori tidak setuju, dimana pemahaman masayarakat terhadap pelaksanaan kebijakan sistem zonasi mencapai $65 \%$ yang termasuk ke dalam kategori tidak setuju serta persepsi masyarakat terhadap sosialisasi pelaksanaan kebijakan sistem zonasi mencapai 57\% dengan kategori tidak setuju. Sehingga dapat dikatakan masyarakat tidak menyetujui dengan adanya atau diberlakukannya kebijakan sistem zonasi.
\end{abstract}

Kata Kunci: kebijakan, sistem zonasi, pendidikan

\section{ABSTRACT}

This study aims to describe the knowledge of the implementation of the zoning policy system, as well as the technical opinion of the implementation of the zoning system policy on the admission of new students at SMP N 18 Padang. This type of research is descriptive with a quantitative approach. The population of this study was 870 and the sample of the study was 90 respondents. With a sampling technique using a probability sampling technique. Where in this study, the 
respondents in question were the guardians of students from grades VII, VII and IX at SMP N 18 Padang. This policy is carried out at the time of admission of new students where the implementation is, prospective students must attend school the closest distance from their domicile or according to the Family Card. The results of this study reached $61 \%$ in the category of disagree, where the public's knowledge of the implementation of the zoning system policy reached $65 \%$ and the public's perception of the technical implementation of the zoning system policy reached $57 \%$. So it can be said that the community does not have a zoning system policy provision.

\section{Keywords: policy, zoning system, education}

(i) (2) This work is licensed under the Creative Commons Attribution-ShareAlike 4.0 International License. (c) 2021 by author.

\section{PENDAHULUAN}

Pendidikan merupakan hal yang sudah melekat pada diri bangsa Indonesia. Serta tolak ukur dari majunya suatu bangsa dan negara ditentukan oleh mutu atau kualitas dari keberlangsungan pendidikan. Seperti halnya dalam negara yang sedang berkembang atau dalam masa pembangunan, peran pendidikan sangatlah penting. Akan tetapi saat ini sering kita jumpai istilah sistem zonasi pada dunia pendidikan. Sistem zonasi menurut Pramudita (2019) kebijakan zonasi adalah sistem penerimaan peserta didik baru yang berdasarkan radius dan jarak terdekat rumah siswa dengan sekolah. Dengan kata lain, siswa harus menuntut ilmu di sekolah yang berdekatan atau satu kawasan dengan tempat tinggalnya berdasarkan alamat di Kartu Keluarga atau domisili. Pada tahun 2018 kebijakan sistem zonasi sudah mulai diberlakukan dalam Penerimaan Peserta Didik Baru (PPDB). Sesuai dengan Pemendikbud NO 14/2018 terdapat pada pasal 16 yang menyebutkan bahwa :

a) Sekolah yang diselenggarakan oleh pemerintah daerah wajib menerima calon peserta didik yang berdomisili pada radius zona terdekat dari Sekolah paling sedikit sebesar 90\% (sembilan puluh persen) dari total jumlah keseluruhan peserta didik yang diterima.

b) Domisili calon peserta didik sebagaimana dimaksud pada ayat (1) berdasarkan alamat pada kartu keluarga yang diterbitkan paling lambat 6 (enam) bulan sebelum pelaksanaan PPDB.

c) Radius zona terdekat sebagaimana dimaksud pada ayat (1) ditetapkan oleh pemerintah daerah sesuai dengan kondisi di daerah tersebut berdasarkan:

a. ketersediaan anak usia Sekolah di daerah tersebut; dan

b. jumlah ketersediaan daya tampung dalam rombongan belajar pada masing-masing Sekolah. 
d) Dalam menetapkan radius zona sebagaimana dimaksud pada ayat (3), pemerintah daerah melibatkan musyawarah/kelompok kerja kepala Sekolah.

e) Bagi Sekolah yang berada provinsi/kabupaten/kota, di daerah ketentuan perbatasan persentase dan radius zona terdekat sebagaimana dimaksud pada ayat (1) dapat diterapkan melalui kesepakatan secara tertulis antarpemerintah daerah yang saling berbatasan.

f) Sekolah yang diselenggarakan oleh pemerintah daerah dapat menerima calon peserta didik melalui:

a. jalur prestasi yang berdomisili diluar radius zona terdekat dari Sekolah paling banyak 5\% (lima persen) dari total jumlah keseluruhan peserta didik yang diterima; dan

b. jalur bagi calon peserta didik yang berdomisili di luar zona terdekat dari Sekolah dengan alasan khusus meliputi perpindahan domisili orangtua/wali peserta didik atau terjadi bencana alam/sosial, banyak $5 \%$ (lima persen) dari total paling jumlah keseluruhan peserta didik yang diterima.

\section{METODE PENELITIAN}

Penelitian ini menggunakan metode kuantitatif deskriptif. Menurut Hermawan (2018) mengungkapkan bahawa metode kuantitatif merupakan sebuah metodologi penelitian yang menekankan kepada angka-angka hasil pengukuran dari analisis tertentu dengan tujuan untuk membuktikan suatu fenomena. Lokasi penelitian ini bertempat di SMP N 18 Padang yang terletak di Balai Baru Kuranji, Kota Padang. Penulis memilih lokasi ini karena penulis ingin mengetahui persepsi masyarakat terhadap pelaksanaan kebijakan sistem zonasi pada penerimaan peserta didik baru di lingkungan sekolah SMP N 18 Padang. Teknik pengumpulan data menggunakan kuesioner berupa angket penelitian. Menurut Sugiyono (2011) kuesioner merupakan teknik pengumpulan data yang dilakukan dengan memberikan pernyataan tertulis kepada responden. Sampel penelitian diambil menggunakan teknik probability sampling berupa Cluster Sampling dimana teknik ini mengambil sampel dengan memberikan peluang yang sama bagi setiap responden, sehingga sampel penelitian berjumlah 90 orang yang didapat dengan rumus Slovin. Adapun uji validitas dalam penelitian ini menggunakan bantuan softwere statistical product and service solution (SPSS) versi 19 yang dilihat dari Corrected Item-Total Correlation dengan hasil $r$ tabel besar dari 0,361 maka dinyatakan valid. Sedangkan reabilitas dalam penelitian ini menggunakan ketentuam Cronbach Alpha dengan hasil $r$ tabel besar dari 0,6 maka dinyatakan reliabel (Nugroho dalam Dewi, 2017). 


\section{HASIL DAN PEMBAHASAN}

\section{Persepsi Masyarakat Terhadap Pelaksanaan Kebijakan Sistem} Zonasi Pada Penerimaan Peserta Didik Baru

Deskripsi hasil pengolahan data dilihat dari dua indikator. Dimana indikator yang pertama yaitu pemahaman masyarakat terhadap pelaksanaan kebijakan sistem zonasi. serta indikator yang kedua adalah mengenai persepsi masyarakat terhadap sosialisasi pelaksanaan kebijakan sistem zonasi. Pada sub variabel ini akan terlihat sejauh mana pemahaman masyarakat terhadap pelaksanaan kebijakan sistem zonasi serta persepsi masyarakat akan sosialisasi terkait dengan sistem zonasi, dilihat dari beberapa pernyataan yang diajukan oleh penulis. Adapun gambarannya dapat dilihat pada tabel dibawah ini:

Tabel 1

Persepsi masyarakat terhadap pemahaman pelaksanaan kebijakan sistem zonasi pada PPDB

\begin{tabular}{|c|c|c|c|c|c|c|c|c|}
\hline \multirow{2}{*}{$\begin{array}{l}\mathbf{N} \\
\mathbf{0}\end{array}$} & \multirow[t]{2}{*}{ Pernyataan } & \multicolumn{4}{|c|}{ Kategori } & \multirow{2}{*}{$\begin{array}{l}\text { Rat } \\
\text { a- } \\
\text { rat } \\
\text { a }\end{array}$} & \multirow[t]{2}{*}{$\%$} & \multirow[t]{2}{*}{ Keterangan } \\
\hline & & SS & S & TS & STS & & & \\
\hline 1 & $\begin{array}{l}\text { Kebijakan sistem } \\
\text { zonasi adalah } \\
\text { peraturan terkait } \\
\text { pendidikan }\end{array}$ & 43 & 39 & 4 & 4 & 3,3 & 83 & $\begin{array}{l}\text { Sangat } \\
\text { Setuju }\end{array}$ \\
\hline 2 & $\begin{array}{l}\text { Kebijakan sistem } \\
\text { zonasi terdapat } \\
\text { dalam } \\
\text { permendikbud }\end{array}$ & 28 & 46 & 8 & 8 & 3 & 75 & Setuju \\
\hline 3 & $\begin{array}{l}\text { Kebijakan sistem } \\
\text { zonasi mulai } \\
\text { diberlakukan } \\
\text { pada tahun } 2018\end{array}$ & 25 & 49 & 9 & 7 & 3 & 75 & Setuju \\
\hline 4 & $\begin{array}{l}\text { Kebijakan sistem } \\
\text { zonasi berlaku } \\
\text { pada } \\
\text { penerimaan } \\
\text { peserta didik } \\
\text { baru }\end{array}$ & 44 & 32 & 9 & 5 & 3,2 & 80 & Setuju \\
\hline 5 & $\begin{array}{lr}\text { Kebijakan } & \text { sistem } \\
\text { zonasi biasa } \\
\text { disebut dengan } \\
\text { istilah rayon }\end{array}$ & 23 & 49 & 10 & 8 & 3 & 75 & Setuju \\
\hline 6 & $\begin{array}{l}\text { Kebijakan sistem } \\
\text { zonasi } \\
\text { diterapkan } \\
\text { kurang lebih } \\
\text { selama } 2 \text { tahun }\end{array}$ & 29 & 40 & 12 & 9 & 3 & 75 & Setuju \\
\hline \multicolumn{2}{|r|}{ Setamia z camina } & & & & & 3 & 77 & Setuju \\
\hline
\end{tabular}


Dari tabel di atas dapat diketahui bahwa responden lebih banyak mengetahui mengenai sistem zonasi sebagai peraturan kebijakan dalam pendidikan, dengan jumlah presentase sebesar $83 \%$. Hal tersebut ditunjukkan pada pernyatan 1 terdapat 43 responden yang mengatakan sangat setuju dan 39 responden yang menyatakan setuju akan hal tersebut. Serta hanya 8 responden yang mengatakan tidak dan sangat tidak setuju mengenai hal tersebut. Sehingga dapat dikatakan bahwa masayarakt mengetahui mengenai sistem zonasi, adalah salah satu aturan yang terdapat dalam peraturan pendidikan.,masayarakat juga sudah cukup mengerti. Seperti yang terlihat pada tabel di atas, pengetahuan pelaksanaan dalam kebijakan sistem zonasi pada indikator pemahaman masyarakat tergolong pada kategori setuju dengan perolehan presentase sebesar $77 \%$.

Tabel 2

Persepsi masyarakat terhdap sosialisasi pelaksanaan kebijakan sistem zonasi

\begin{tabular}{|c|c|c|c|c|c|c|c|c|}
\hline & \multirow[t]{2}{*}{ pernyataan } & \multicolumn{4}{|c|}{ Kategori } & \multirow{2}{*}{$\begin{array}{l}\text { Rata } \\
\text {-rata }\end{array}$} & \multirow[t]{2}{*}{$\%$} & \multirow{2}{*}{$\begin{array}{l}\text { Keterang } \\
\text { an }\end{array}$} \\
\hline 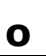 & & SS & S & TS & STS & & & \\
\hline 1 & $\begin{array}{l}\text { Adanya } \\
\text { sosialisasi yang } \\
\text { diberikan terkait } \\
\text { sistem zonasi } \\
\text { dari pemerintah } \\
\text { setemnat }\end{array}$ & 11 & 11 & 39 & 29 & 2 & 50 & $\begin{array}{l}\text { Tidak } \\
\text { setuju }\end{array}$ \\
\hline 2 & \begin{tabular}{lr|}
\multicolumn{2}{|l|}{ Sosialisasi } \\
terkait & sistem \\
zonasi & sudah \\
dilakukan & secara \\
optimal & \\
\end{tabular} & 11 & 13 & 34 & 32 & 2 & 50 & $\begin{array}{l}\text { Tidak } \\
\text { Setuju }\end{array}$ \\
\hline 3 & $\begin{array}{l}\text { Perlunya } \\
\text { sosialisasi yang } \\
\text { diberikan kepada } \\
\text { masyarakat } \\
\text { terkait sistem } \\
\text { zonasi }\end{array}$ & 14 & 35 & 24 & 17 & 2,5 & 63 & Setuju \\
\hline 4 & $\begin{array}{l}\text { Sosialisasi } \\
\text { terkait sistem } \\
\text { zonasi } \\
\text { memberikan } \\
\text { dampak positif } \\
\text { kepada } \\
\text { masyarakat }\end{array}$ & 18 & 10 & 35 & 27 & 2,2 & 55 & $\begin{array}{l}\text { Tidak } \\
\text { Setuju }\end{array}$ \\
\hline 5 & $\begin{array}{l}\text { Sosialisasi } \\
\text { membantu } \\
\text { pemahaman } \\
\text { masyarakat } \\
\text { terkait sistem } \\
\text { zonasi }\end{array}$ & 10 & 10 & 32 & 38 & 2 & 50 & $\begin{array}{l}\text { Tidak } \\
\text { Setuju }\end{array}$ \\
\hline
\end{tabular}




\begin{tabular}{|l|l|l|l|l|l|l|l|l|}
\hline 6 & $\begin{array}{l}\text { Persepsi } \\
\text { masyarakat } \\
\text { berubah terkait } \\
\text { sistem zonasi, } \\
\text { karena sudah } \\
\text { dilakukan } \\
\text { sosialisasi }\end{array}$ & 8 & 14 & 44 & 24 & 2 & 50 & $\begin{array}{l}\text { Tidak } \\
\text { Setuju }\end{array}$ \\
\hline Jumlah & & 2 & 53 & $\begin{array}{l}\text { Tidak } \\
\text { Setuju }\end{array}$ \\
\hline
\end{tabular}

Dari tabel di atas dapat diketahui bahwa responden sangat mengharapkan adanya sosialisasi yang efektif terkait dengan diberlakukannya kebijakan sistem zonasi. Sesuai dengan data yang ada bahwa terdapat 49 responden yang mengatakan sangat setuju dan setuju supaya sosialisasi tersebut dapat diberikan kepada masyarakat, dan hanya 41 responden yang menyatakan tidak serta sangat tidak setuju dengan diberlakukannya sosialisasi mengenai kebijakan sistem zonasi. Perbedaan pendapat ini disebabkan karena beberapa faktor. Salah satu faktor yang sangat mendasari hal tersebut adalah adanya perbedaan persepsi dari masyarakat dalam hal ini adalah wali murid di SMP N 18 Padang.

Tabel di atas juga menunjukkan bahwa kurangnya sosialisasi yang diberikan kepada masyarakat. Ini terlihat dari data yang ada bahwa tanggapan masyarakat mengenai sosialisasi yang diberikan kepada masyarakat sangatlah rendah dengan pencapaian 53\%. Capaian ini termasuk kedalam kategori tidak setuju. Sehingga persepsi masyarakat terhadap kebijakan sistem zonasi pada penerimaan peserta didik baru masih sangat beragam dan belum bisa untuk diseragamkan. Berdasarkan uraian tabel 1 dan 2 di atas, maka dapat dibuat rekapitulasi hasil pengolahan data persepsi masyarakat terhadap pengetahuan pelaksanaan kebijakan sistem zonasi pada penerimaaan peserta didi baru pada tabel berikut :

Tabel 3

Rekapitulasi persepsi masyarakat terhadap pengetahuan pelaksanaan kebijakan sistem zonasi pada PPDB

\begin{tabular}{|l|l|l|l|l|}
\hline NO & Indikator & $\begin{array}{l}\text { Rata- } \\
\text { Rata }\end{array}$ & $\%$ & Kategori \\
\hline 1 & $\begin{array}{l}\text { Persepsi masyarakat terhadap } \\
\text { pemahaman kebijakan sistem } \\
\text { zonasi pada penerimaan peserta } \\
\text { didik baru }\end{array}$ & 3 & 77 & Setuju \\
\hline 2 & $\begin{array}{l}\text { Persepsi masyarakat terhadap } \\
\text { sosialisasi pelaksanaan kebijakan } \\
\text { sistem zonasi }\end{array}$ & 2 & 53 & Tidak Setuju \\
\hline Rata-Rata & 2,5 & 65 & Setuju \\
\hline
\end{tabular}


Dari hasil tabel di atas dapat diketahui bahwa dari dua indikator yang dilihat terdapat perbedaan yang sangat mencolok dimana dalam indikator pemahaman masyarakat terkait dengan diberlakukannya kebijakan sistem zonasi sudah mencapai pada pencapaian $77 \%$ dengan kategori setuju. Berbeda halnya dengan indikator sosialisasi yang diberikan terkait dengan diberlakukannya kebijakan sistem zonasi, yang berada pada kategori sangat rendah yaitu $53 \%$ dengan kategori tidak setuju. Sehingga dapat dikatakan bahwa, masyarakat yang dalam hal ini adalah wali murid di SMP N 18 Padang, sudah mengetahui mengenai kebijakan sistem zonasi yang dibuktikan dengan $65 \%$ tingkat pencapaian presentase dengan kategori setuju. Akan tetapi, meskipun masyarakat sudah mengetahui akan adanya kebijakan sistem zonasi, masyarakat juga masih memerlukan sosialisasi yang diberikan baik dari pihak sekolah, pemerintah setempat maupun pemerintah pusat. Sehingga persepsi masyarakat terhadap kebijakan sistem zonasi dapat diseragamkan dan tidak lagi terdapat kubu-kubu dalam menanggapi kebijakan tersebut.

\section{KESIMPULAN}

Berdasarkan analisis data dan pembahasan maka dapat diambil kesimpulan bahwa persepsi masyarakat pelaksanaan kebijkan sistem zonasi berada pada kategori setuju, yaitu masyarakat dalam hal ini adalah wali murid di SMP N 18 Padang sudah mengerti serta memahami mengenai kebijakan sistem zonasi dengan presentase $65 \%$. Namun pada hal tersebut juga terlihat adanya perbedaan persepsi antar masyarakat mengenai kebijakan sistem zonasi.

\section{DAFTAR PUSTAKA}

Aina.2015. Pendidikan Politik bagi Generasi Muda melalui Partai Politik Vol.5 No.1 2015. Algensindo Offset

Dharma, S. (2008). Strategi Pembelajaran dan Pemilihannya. Strategi Pembelajaran Dan Pemilihannya, 57.

Halking. 2018. Aspek-aspek Pendidikan Politik dalam Kehidupan demokrasi untuk Mewujudkan Kecakapan Warga Negara yang Smart and Good Citizenship. Seminar Nasional Hukum Univers itas Negeri Semarang. Volume.4 No. 3 2018, 1205-1228.

Herdiansyah, Haris. 2010. Metode Penelitian Kualitatif. Bandung: CV. AlfaBeta

Indrakusuma. 1997. Ilmu Pendidikan. Surabaya: Usaha Nasional

Iskandar. 2008. Metodologi Penelitian Pendidikan dan Sosial (Kuantitatif dan Kualitatif). Jakarta: Gaung Persada Group

Meleong. 2005. Metode Penelitian Kualitatif. Bandung: Alfabeta

Purwanto Ngalim. 2000. Ilmu Pendidikan Teoritis dan Praktik Bandung: Remaja

Ritonga, Rahman. 1997. Statistika untuk Penelitian Psikologi dan Penelitian. Jakarta: Lembaga Penerbit Fakultas Ekonomi UI. Rosdakarya 
38 | Persepsi wali murid...

Sadirman. 2014. Interaksi dan Motivasi Belajar Mengajar. Jakarta: Garfindo Persada

Sanafiah Faisal. 1990. Penelitian Kualitatif: Dasar-Dasar dan Aplikasi. Malang: YA3

Slameto. 2010. Belajar dan Faktor yang Mempengaruhinya. Jakarta: Rineka Cipta

Sudjana Nana. 2004. Dasar-Dasar Proses Belajar Mengajar. Bandung: Sinar Baru

Sugiyono. 2003. Metode Penelitian Bisnis. Bandung. Pusat Bahasa Depdiknas.

Sugiyono. 2012. Metode Penelitian Pendidikan Pendekatan Kuantitatif, Kualitatif, dan R\&D. Bandung: ALFABETA. 2012 (cet. 15)

Sugiyono. 2017. Metode Penelitian Kuantitatif, Kualitatif dan R\&D. Bandung: CV. Alfabeta

Suharsimi Arikunto. 2006. Prosedur Penelitian: Suatu Pendekatan Praktik. Jakarta: PT Rineka Cipta

Sunarso.2007. Pendidikan Politik dan Politik Pendidikan. Jurnal civic Volume.4 No.2, Desember 2007

Undang-undang Republik Indonesia Nomor 12 Tahun 2012 Tentang Pendidikan Tinggi 